\title{
APLIKASI PEMBELAJARAN YOGA HINDU BERBASIS ANDROID
}

\author{
${ }^{1}$ Kadek Ardiago, ${ }^{2}$ Machudor Yusman \& ${ }^{3}$ Wayan Rumite \\ ${ }^{1,2}$ Jurusan Ilmu Komputer FMIPA Universitas Lampung \\ ${ }^{3}$ Jurusan Pendidikan MIPA FKIP Universitas Lampung \\ ${ }^{1}$ kadekardiago@gmail.com ${ }_{2}^{2}$ machudor@unila.ac.id. ${ }_{2}^{3}$ wayan.rumite@gmail.com
}

\begin{abstract}
Yoga, in Hindu philosophy, focuses on meditation activities or tapa where ones focuses all thoughts to control the five senses and the body as a whole. The rapid progress of information and communication technology and the lack of Hindu Yoga learning media in digital form have encouraged the development of Hindu Yoga Learning Applications Android-based. This application is expected to be a practical and interesting learning media to be learnt, as well as a reference in learning the movements of Hatha Yoga and Surya Namaskara besides books. This study has succeeded in developing an Android Application of Hindu Yoga Learning consisting of 46 Yoga movements, among others, 12 (twelve) Surya Namaskara movements, 8 (eight) pranayama movements, 7 (seven) sitting position of asanas movements, 8 standing position of asanas movements and 11 (eleven) sleep position of asanas movements. This application runs on the Android operating system so that it can be accessed by everyone and at any time on a smartphone or tablet computer that supports the Android operating system. The conclusion of this study is that the Hindu Yoga Learning Applications Android-based has been successfully built and it has been tested to match with the expected result.
\end{abstract}

Keywords: application, hindu yoga, android.

\section{Pendahuluan}

Teknologi merupakan alat yang digunakan untuk mempermudah pekerjaan manusia. Dengan teknologi manusia dapat memperoleh informasi dari berbagai penjuru dunia dan dapat saling terhubung satu sama lain dengan individu atau kelompok dengan cakupan global. Salah satu teknologi yang sedang berkembang yang banyak digunakan untuk memperoleh informasi yaitu smartphone Android. Menurut [1] smartphone adalah telepon genggam yang mempunyai kemampuan dengan fungsi yang menyerupai komputer. Smartphone merupakan alat modern yang tidak bisa dilepaskan dari kehidupan sehari-hari karena memiliki ukuran yang kecil sehingga memungkinkan pengguna untuk membawa smartphone kemana saja, selain itu smartphone juga dapat mempermudah pengguna untuk terhubung satu sama lain, memperoleh informasi, dan melakukan kegiatan multitasking dengan satu genggaman. Smartphone berbasis Android merupakan smartphone yang paling banyak digunakan di indonesia bahkan di dunia. Android merupakan sistem operasi yang dikembangkan untuk perangkat mobile berbasis Linux [2]. Bahasa pemrograman yang digunakan Android adalah Java.

Kemajuan teknologi informasi dan komunikasi harus diimbangi dengan pemahaman Agama yang baik untuk meningkatkan jiwa spiritualitas dari pengguna teknologi. Dalam ajaran Agama Hindu, Yoga merupakan ajaran dalam filsafat Hindu yang menitikberatkan pada aktivitas meditasi atau tapa dimana seseorang memusatkan seluruh pikiran untuk mengontrol panca indera dan tubuhnya secara keseluruhan. Yoga merupakan aktivitas penyatuan antara Atman (diri) dan Tuhan [3]. Melalui yoga seseorang dapat lebih mengenal tubuhnya, mengenal fikirannya, dan mengenal jiwanya. Semakin seseorang mengenal seluruh aspek dirinya, maka semakin dekat seseorang dengan Tuhan. 
Perkembangan teknologi yang pesat dan minimnya media pembelajaran Yoga Hindu dalam bentuk digital mendorong dikembangkannya Aplikasi Pembelajaran Yoga Hindu Berbasis Android. Dengan memanfaatkan perkembangan teknologi diharapkan belajar gerakan yoga menjadi lebih praktis dan menarik untuk dipelajari dan Yoga Hindu tetap eksis mengikuti perkembangan jaman. Aplikasi Pembelajaran Yoga Hindu Berbasis Android menitikberatkan pada gerakan Hatha Yoga dan Surya Namaskara. Aplikasi Pembelajaran Yoga Hindu Berbasis Android menitikberatkan pada gerakan Hatha Yoga dan Surya Namaskara. Menurut [3] menyatakan bahwa Hatha yoga merupakan gerakan yang berpusat pada penguasaan tubuh maupun pernafasan. Surya Namaskara merupakan perpaduan gerak, pernafasan dan konsentrasi menuntun pikiran terarah, terfokus untuk membuka selubung atau lapisan-lapisan yang ada dalam tubuh manusia [4].

Terkait pemaparan permasalahan yang ada, menjadi sangat penting dilakukan penelitian tentang bagaimana cara mengembangkan Aplikasi Pembelajaran Yoga Hindu Berbasis Android agar belajar gerakan yoga menjadi lebih praktis untuk dipelajari sesuai dengan perkembangan jaman, sehingga pengembangan Aplikasi Pembelajaran Yoga Hindu Berbasis Android diharapkan dapat menjadi acuan user dalam mencari referensi gerakan yoga dan membuat belajar yoga menjadi lebih praktis dan menarik untuk dipelajari. Aplikasi Pembelajaran Yoga Hindu Berbasis Android juga diharapkan dapat diakses siapa saja dan kapan saja di smartphone atau Komputer tablet, serta meningkatkan minat belajar user, serta user dapat mempraktekkan gerakan Hatha Yoga dan Surya Namaskara dalam kehidupan sehari-hari.

Dalam pengembangannya, Aplikasi Pembelajaran Yoga Hindu Berbasis Android hanya dapat dioperasikan dalam smartphone yang mendukung OS (Operating System) Android dengan versi terendah 4.0 (Ice Cream Sandwich). Pengembangan Aplikasi Pembelajaran Yoga Hindu Berbasis Android menggunakan bahasa pemrograman Java pada aplikasi Android Studio. Aplikasi Pembelajaran Yoga Hindu Berbasis Android merupakan aplikasi pembelajaran gerakan Hatha Yoga dan Surya Namaskara. Aplikasi Pembelajaran Yoga Hindu Berbasis Android dibuat untuk meningkatkan minat belajar Hatha Yoga dan Surya Namaskara secara praktis pada tingkatan Universitas khususnya mahasiswa Hindu Unila.

\section{Metodologi Penelitian}

Penelitian dilakukan di Universitas Lampung dan UKM Hindu Unila yang berada di Jalan

Soemantri Brojonegoro No.1 Gedung Meneng, Bandar Lampung.

Penelitian ini menggunakan peralatan pendukung sebagai berikut.

1. Perangkat Keras (hardware)

Perangkat keras yang digunakan dalam penelitian ini laptop dengan spesifikasi sebagai berikut.

$>$ Processor : Intel(R) Core(TM) i3-4010U CPU @ 1.70GHz (4CPUs)

$>$ Installed RAM : $4.00 \mathrm{~GB}$.

$>$ System Type : :64-bit operating system, x64-based processor.

2. Perangkat Lunak (software)

Perangkat lunak yang digunakan dalam penelitian ini adalah sebagai berikut.

$>$ Sistem Operasi : Windows 7 Ultimate 64-bit

$>$ Star UML

$>$ Android Studio

$>$ Microsoft Office Word 2013

$>$ CorelDraw X7

$>$ Photoshop

$>$ Adobe Premiere 


\section{Perangkat keras tambahan}

Perangkat keras tambahan yang digunakan dalam penelitian ini adalah smartphone yang digunakan sebagai emulator pada aplikasi Android Studio yang memiliki spesifikasi sebagai berikut.
$>$ Processor
: Snapdragon 625
$>$ Installed RAM
: $3 \mathrm{~GB}$
$>$ Sistem Operation : Android 7.0 (Nougat)

Dalam mendukung pembuatan sistem, dilakukan pengumpulan data dengan menggunakan dua metode dalam mengumpulkan data yaitu melalui Observasi dan studi pustaka.

Gambar 1 adalah diagram alir tahapan penelitian Aplikasi Pembelajaran Yoga Hindu berbasis Android. Tahapan penelitian ini memiliki beberapa langkah yang harus dilakukan yaitu tahapan pengumpulan data, tahapan Extreme Programming, penulisan laporan, dan release Aplikasi. Tahapan Extreme Programming meliputi Planning, Design, Coding, dan Testing. Dimana proses Planning merupakan tahapan awal dalam Extreme Programming yaitu membuat gambaran output, fitur dan fungsi-fungsi dari perangkat lunak. Design pada pengembangan Aplikasi Pembelajaran Yoga Hindu berbasis Android meliputi perancangan Use Case Diagram, Activity Diagram dan desin interface dari Aplikasi Pembelajaran Yoga Hindu berbasis Android. Coding merupakan proses penulisan program Aplikasi Pembelajaran Yoga Hindu berbasis Android yang dilakukan dengan menggunakan Software Android Studio. Kemudian Testing merupakan uji coba dari program yang dibangun untuk mengetahui apakah ada kesalahan pada penulisan program dan untuk mengetahui apakah semua fitur sudah dapat berjalan dengan baik.

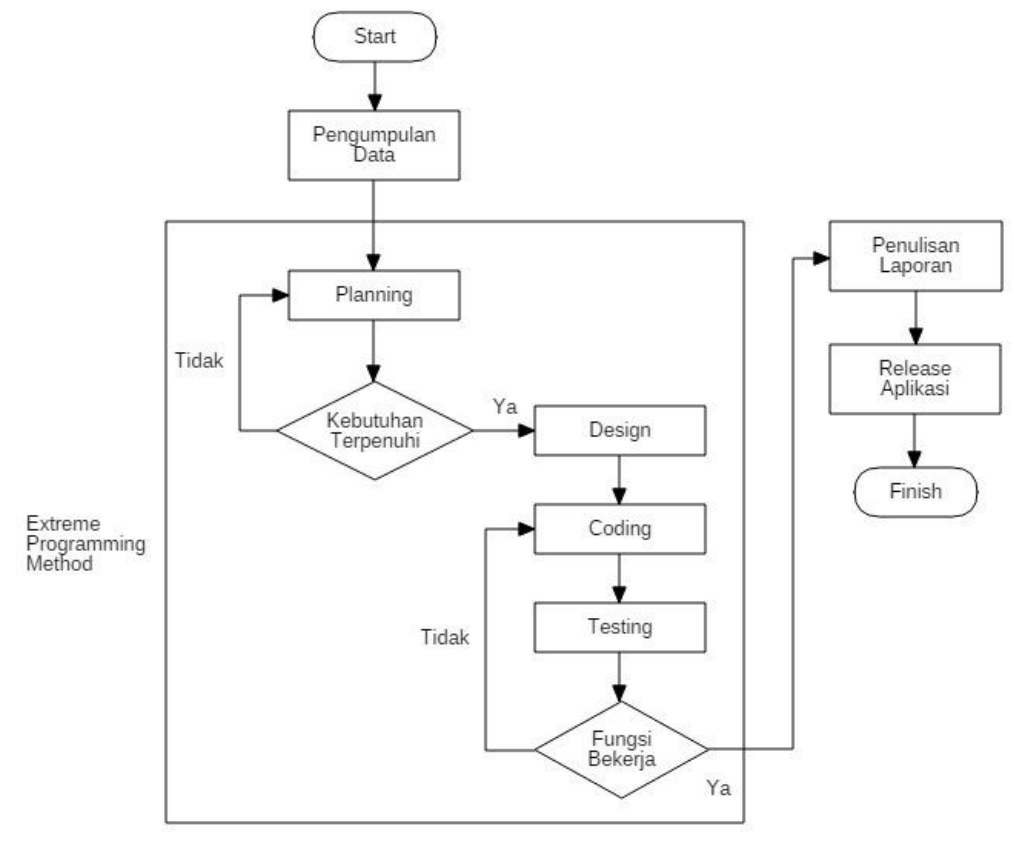

Gambar 1 Diagram Alir.

\section{Hasil Penelitian}

Aplikasi Pembelajaran Yoga Hindu berbasis Android ini dibangun menggunakan bahasa pemrograman Java dengan menggunakan kerangka kerja android yang kode programnya ditulis menggunakan IDE Android Studio. Aplikasi pembelajaran yoga hindu berbasis android terdiri dari 46 gerakan yoga antara lain, 12 (dua belas) gerakan Surya Namaskara, 8 (delapan) gerakan pranayama, 7 (tujuh) gerakan asanas posisi duduk, 8 gerakan asanas posisi berdiri, dan 11 
(sebelas) gerakan asanas posisi tidur. Aplikasi pembelajaran yoga hindu berbasis android berjalan pada sistem operasi android dengan versi android terendah 4.0 (Ice Cream Sandwich). Untuk mendesain tampilan antarmuka digunakan perangkat lunak CorelDraw X7. Selain itu juga Adobe Photoshop untuk mengedit gambar gerakan yoga, serta perangkat lunak Adobe Premiere untuk mengedit video Surya Namaskara. Aplikasi pembelajaran yoga hindu berbasis android juga menggunakan YouTube Application Programming Interface atau YouTube API, yang memungkinkan pengembang mengakses statistik video dan data saluran Youtube.

Gambar 2 adalah tampilan dari Aplikasi Pembelajaran Yoga Hindu berbasis Android yang terdiri dari 5 (lima) menu utama yaitu Menu Pengenalan Yoga, Hatha Yoga, Surya Namaskara, Bantuan, dan Tentang aplikasi.

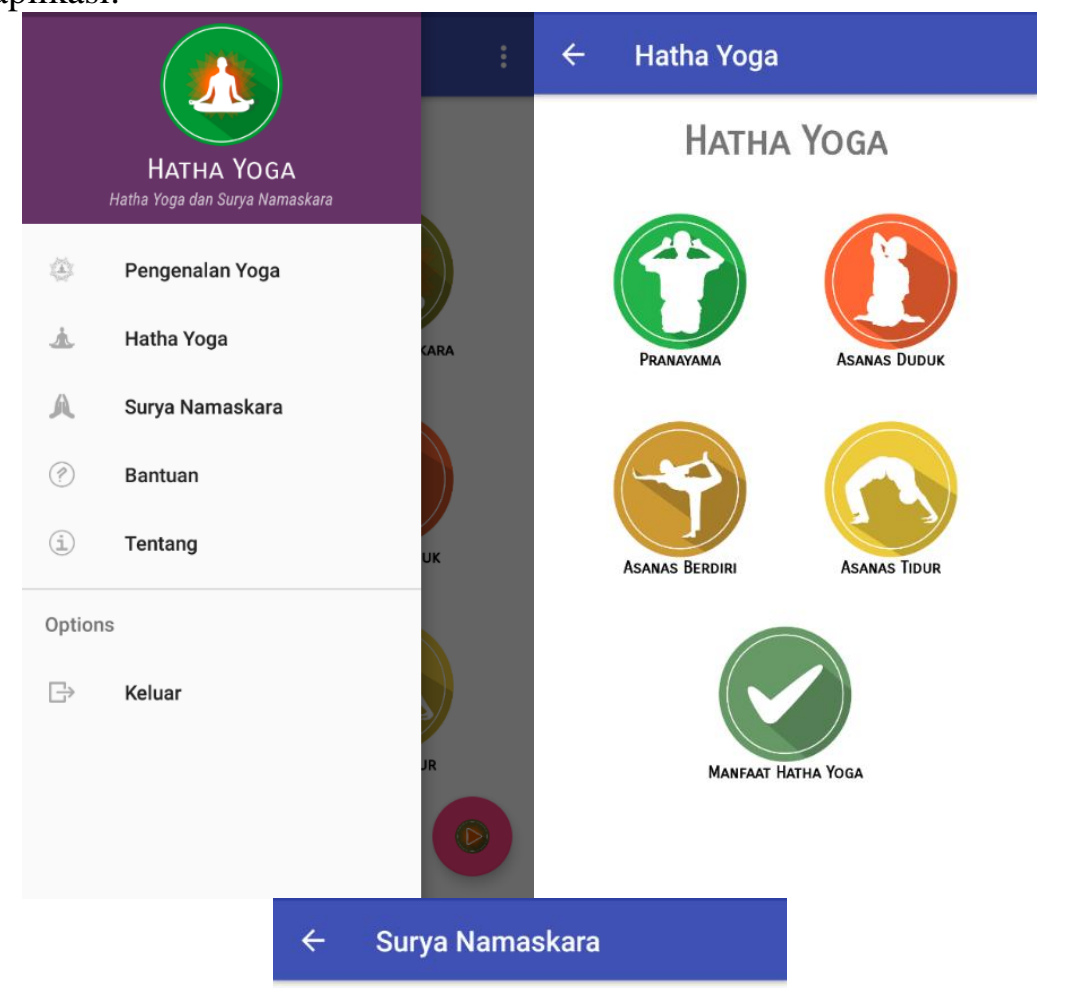

SURYA NAMASKARA
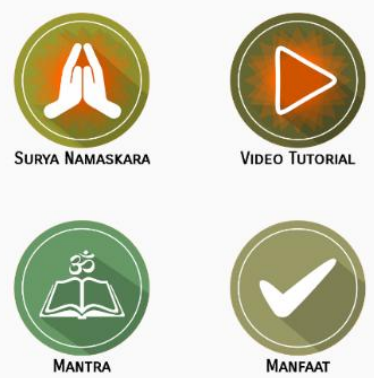

Gambar 2 Tampilan Aplikasi Pembelajaran Yoga Hindu berbasis Android. 
Tampilan Pengenalan Yoga adalah halaman yang dapat diakses setelah pengguna memilih menu pengenalan yoga. Tampilan Pengenalan Yoga menampilkan deskripsi pengenalan yoga, surya namaskara, dan hatha yoga. Tampilan Hatha Yoga adalah halaman yang dapat diakses setelah pengguna memilih Menu Hatha Yoga. Tampilan Hatha Yoga menampilkan Sub Menu Pranayama, Asanas Duduk, Asanas Berdiri, Asanas Tidur, dan Manfaat Hatha Yoga. Tampilan Menu Surya Namaskara adalah halaman yang dapat diakses setelah pengguna memilih menu surya namaskara dari Navigation drawer. Tampilan Menu Surya Namaskara menampilkan sub menu gerakan surya namaskara, video tutorial, mantra surya namaskara, dan manfaat surya namaskara. Tampilan Menu Bantuan adalah halaman yang dapat diakses setelah pengguna memilih menu bantuan dari menu pada Navigation drawer. Menu Bantuan menampilkan panduan singkat pengoperasian aplikasi. Selain itu, pada tampilan menu bantuan juga berisi button untuk mengirim saran atau masukan beserta laporan bug aplikasi melalui Gmail. Tampilan Menu Tentang adalah halaman yang dapat diakses setelah pengguna memilih menu tentang dari menu pada navigation drawer. Tampilan Menu Tentang menampilkan deskripsi dari Aplikasi Pembelajaran Yoga Hindu berbasis Android.

\section{Hasil Pengujian}

\section{Pengujian Fungsional}

Pada penelitian ini, pengujian sistem dilakukan menggunakan metode pengujian black box equivalence partioning di mana pengujian ini dilakukan dengan membagi domain input ke dalam kelas-kelas sehingga test case dapat diperoleh. Pengujian dilaksanakan pada September 2018. Beberapa pengujian yang dilakukan antara lain pengujian versi android, pengujian resolusi layar dan densitas layar, dan pengujian fungsional menu aplikasi.

Pada pengujian versi android terdapat 6 versi android yang tidak kompatibel dengan aplikasi dari total 13 versi android yang diujikan. Keenam versi android yang tidak kompatibel tersebut antara lain versi 1.5 (Cupcake), 1.6 (Donut), 2.0-2.1 (Eclair), 2.2-2.2.3 (Froyo), 2.3-2.3.7 (GingerBread), dan 3.0-3.2 (HoneyComb). Alasan keenam versi tersebut tidak kompatibel dengan aplikasi pembelajaran yoga hindu berbasis android adalah versi-versi tersebut merupakan versi lama dan sudah tidak lagi digunakan, sehingga penulis tidak dapat menemukan smartphone yang masih menggunakan versi android tersebut baik smartphone asli maupun emulator. Apabila pengujian terhadap aplikasi tetap dilakukan menggunakan keenam versi android tersebut, kemungkinan yang akan terjadi adalah aplikasi tidak dapat berfungsi sebagaimana mestinya dikarenakan versi tersebut tidak didukung oleh versi kode program yang digunakan oleh penulis. Pada pengujian resolusi dan densitas layar, secara keseluruhan hasil pengujian telah sesuai dengan hasil yang diharapkan. Hasil pengujian menunjukkan bahwa seluruh jenis resolusi layar yang diujikan telah sesuai dan proporsional terhadap tampilan aplikasi, maupun dengan ratio layar smartphone terbaru yaitu 18:9.

Pada pengujian fungsional aplikasi pembelajaran yoga hindu berbasis android, secara keseluruhan hasil pengujian telah sesuai dengan hasil yang diharapkan. Hasil pengujian menunjukkan bahwa fungsi-fungsi pada aplikasi telah dapat berjalan dengan baik sesuai dengan masukkan yang diberikan.

\section{Pengujian Kepuasan Pelanggan}

Untuk mendukung hasil pengujian fungsional yang telah dibahas sebelumnya, penulis telah melakukan pengujian tingkat kepuasan pengguna melalui kuisioner terhadap 43 orang responden. Pertanyaan yang diberikan didasarkan pada pengujian-pengujian yang telah dirancang yakni 
mengenai versi Android, resolusi dan densitas layar, serta fungsional aplikasi. Rincian jawaban kuisioner oleh responden dapat dilihat pada Tabel 1.

Tabel 1 Rincian Jawaban Kuisioner

\begin{tabular}{|c|c|c|c|c|c|c|c|c|}
\hline \multirow{3}{*}{ No. } & \multirow{3}{*}{ Pertanyaan } & \multicolumn{5}{|c|}{ Skor Skala } & \multirow{3}{*}{ Total } & \multirow{3}{*}{$\begin{array}{c}\text { Rata- } \\
\text { rata }(\%)\end{array}$} \\
\hline & & SB & B & CB & $\mathbf{K B}$ & TB & & \\
\hline & & 5 & 4 & 3 & 2 & 1 & & \\
\hline 1 & $\begin{array}{l}\text { Aplikasi dapat berjalan } \\
\text { dengan baik pada versi } \\
\text { android yang digunakan }\end{array}$ & 26 & 16 & 1 & 0 & 0 & 197 & $91,63 \%$ \\
\hline 2 & $\begin{array}{l}\text { Aplikasi dapat menampil- } \\
\text { kan pengenalan yoga }\end{array}$ & 27 & 15 & 1 & 0 & 0 & 198 & $92,09 \%$ \\
\hline 3 & $\begin{array}{l}\text { Aplikasi dapat menampil- } \\
\text { kan gerakan Hatha Yoga } \\
\text { (Pranayama, Asanas Duduk, } \\
\text { Asanas Berdiri, Asanas } \\
\text { Tidur) }\end{array}$ & 25 & 17 & 1 & 0 & 0 & 196 & $91,16 \%$ \\
\hline 4 & $\begin{array}{l}\text { Aplikasi dapat menampil- } \\
\text { kan Manfaat Hatha yoga }\end{array}$ & 28 & 11 & 4 & 0 & 0 & 196 & $91,16 \%$ \\
\hline 5 & $\begin{array}{l}\text { Aplikasi dapat menampil- } \\
\text { kan gerakan Surya } \\
\text { Namaskara }\end{array}$ & 23 & 19 & 1 & 0 & 0 & 194 & $90,23 \%$ \\
\hline 6 & $\begin{array}{l}\text { Aplikasi dapat menampil- } \\
\text { kan Video Tutorial Surya } \\
\text { Namaskara }\end{array}$ & 24 & 18 & 1 & 0 & 0 & 195 & $90,70 \%$ \\
\hline 7 & $\begin{array}{l}\text { Aplikasi dapat menampil- } \\
\text { kan Mantra Surya } \\
\text { Namaskara }\end{array}$ & 27 & 14 & 2 & 0 & 0 & 197 & $91,63 \%$ \\
\hline 8 & $\begin{array}{l}\text { Aplikasi dapat menampil- } \\
\text { kan Manfaat Surya } \\
\text { Namaskara }\end{array}$ & 28 & 13 & 2 & 0 & 0 & 198 & $92,09 \%$ \\
\hline 9 & $\begin{array}{l}\text { Aplikasi dapat menampil- } \\
\text { kan Menu Bantuan }\end{array}$ & 23 & 18 & 2 & 0 & 0 & 193 & $89,77 \%$ \\
\hline 10 & $\begin{array}{l}\text { Aplikasi dapat menampil- } \\
\text { kan Tentang Aplikasi }\end{array}$ & 24 & 15 & 4 & 0 & 0 & 192 & $89,30 \%$ \\
\hline 11 & $\begin{array}{l}\text { Aplikasi dapat mengakses } \\
\text { Keluar Aplikasi }\end{array}$ & 27 & 13 & 3 & 0 & 0 & 196 & $91,16 \%$ \\
\hline 12 & $\begin{array}{l}\text { Aplikasi mudah diguna-kan } \\
\text { dan dipahami }\end{array}$ & 29 & 14 & 0 & 0 & 0 & 201 & $93,49 \%$ \\
\hline 13 & $\begin{array}{l}\text { Aplikasi memiliki teks yang } \\
\text { mudah dibaca }\end{array}$ & 31 & 10 & 2 & 0 & 0 & 201 & $93,49 \%$ \\
\hline 14 & $\begin{array}{l}\text { Aplikasi memiliki tampilan } \\
\text { yang nyaman untuk dilihat }\end{array}$ & 27 & 16 & 0 & 0 & 0 & 199 & $92,56 \%$ \\
\hline 15 & $\begin{array}{l}\text { Aplikasi memiliki tampi-lan } \\
\text { sesuai/proporsional dengan } \\
\text { resolusi layar smartphone }\end{array}$ & 25 & 17 & 1 & 0 & 0 & 196 & $93,49 \%$ \\
\hline
\end{tabular}


Tabel 4 Interval Kategori Penilaian Skala Likert

\begin{tabular}{cc}
\hline Interval & Kategori \\
\hline $80 \%-100 \%$ & Sangat baik (5) \\
\hline $60 \%-79,99 \%$ & Baik (4) \\
\hline $40 \%-59,99 \%$ & Cukup baik (3) \\
\hline $20 \%-39,99 \%$ & Kurang Baik (2) \\
\hline $0 \%-19,99 \%$ & Tidak Baik (1) \\
\hline
\end{tabular}

Berdasarkan kategori penilaian skala likert pada Tabel 4.15, hasil pengujian menggunakan skala likert dapat dikategorikan Sangat Baik dengan nilai rata-rata 91,60\%.

\section{Analisa Hasil Pengujian}

Pengujian yang telah dilakukan antara lain yaitu pengujian versi android, pengujian resolusi dan densitas layar, pengujian fungsional aplikasi, serta pengujian kepuasan pelanggan.

Pada pengujian versi android terdapat 6 versi android yang tidak kompatibel dengan aplikasi dari total 13 versi android yang diujikan. Keenam versi android yang tidak kompatibel tersebut antara lain versi 1.5 (Cupcake), 1.6 (Donut), 2.0-2.1 (Eclair), 2.2-2.2.3 (Froyo), 2.3-2.3.7 (GingerBread), dan 3.0-3.2 (HoneyComb). Alasan keenam versi tersebut tidak kompatibel dengan aplikasi pembelajaran yoga hindu berbasis android adalah versi-versi tersebut merupakan versi lama dan sudah tidak lagi digunakan, sehingga penulis tidak dapat menemukan smartphone yang masih menggunakan versi android tersebut baik smartphone asli maupun emulator. Apabila pengujian terhadap aplikasi tetap dilakukan menggunakan keenam versi android tersebut, kemungkinan yang akan terjadi adalah aplikasi tidak dapat berfungsi sebagaimana mestinya dikarenakan versi tersebut tidak didukung oleh versi kode program yang digunakan oleh penulis. Pada pengujian resolusi dan densitas layar, secara keseluruhan hasil pengujian telah sesuai dengan hasil yang diharapkan. Hasil pengujian menunjukkan bahwa seluruh jenis resolusi layar yang diujikan telah sesuai dan proporsional terhadap tampilan aplikasi, maupun dengan ratio layar smartphone terbaru yaitu 18:9.

Pada pengujian fungsional aplikasi pembelajaran yoga hindu berbasis android, secara keseluruhan hasil pengujian telah sesuai dengan hasil yang diharapkan. Hasil pengujian menunjukkan bahwa fungsi-fungsi pada aplikasi telah dapat berjalan dengan baik sesuai dengan masukkan yang diberikan, meskipun ada satu kasus dimana aplikasi mengalami force close saat mengakses manfaat surya namaskara.

Pada saat melakukan pengujian kepuasan pelanggan terhadap aplikasi pembelajaran yoga hindu berbasis android, penilaian untuk kepuasan berada pada rata-rata $91,60 \%$ atau dalam kategori "Sangat Baik" menurut perhitungan menggunakan skala likert. Pada saat melakukan pengujian kepuasan pelanggan terhadap aplikasi pembelajaran yoga hindu berbasis android juga terdapat beberapa masukan untuk meningkatkan efektivitas penggunaan aplikasi antara lain menambahkan fitur alarm yang berfungsi untuk mengingatkan pengguna terhadap waktu yang baik dalam melakukan gerakan yoga, masukan selanjutnya yaitu menambahkan suara pada mantra atau doa untuk pengejaan bacaan mantra yang baik dan benar, kemudian masukan selanjutnya yaitu menambahkan gerakan yoga lainnya supaya aplikasi pembelajaran yoga hindu menjadi aplikasi yoga dengan gerakan yoga terlengkap. Dari masukan tersebut untuk meningkatkan tingkat kepuasan pelanggan, beberapa masukan akan dipertimbangkan untuk update atau pengembangan aplikasi pembelajaran yoga hindu berbasis android selanjutnya. 


\section{Kesimpulan}

Berdasarkan hasil penelitian yang telah dilakukan, dapat disimpulkan Aplikasi Pembelajaran Yoga Hindu Berbasis Android telah berhasil dikembangkan. Aplikasi ini berhasil menampilkan 46 gerakan Yoga antara lain, 12 (dua belas) gerakan Surya Namaskara, 8 (delapan) gerakan pranayama, 7 (tujuh) gerakan Asanas posisi duduk, 8 gerakan Asanas posisi berdiri, dan 11 (sebelas) gerakan Asanas posisi tidur. Hasil pengujian Black Box Equivalence Partitioning pada versi android, Aplikasi Pembelajaran Yoga Hindu Berbasis Android berjalan dengan baik pada versi android 4.0 - 4.0.4 (Ice Cream Sandwich) keatas. Hasil pengujian Black Box Equivalence Partitioning pada resolusi dan densitas layar, tampilan Aplikasi Pembelajaran Yoga Hindu Berbasis Android telah sesuai dan proporsional dengan seluruh jenis resolusi layar yang diujikan. Hasil pengujian Black Box Equivalence Partitioning pada fungsional aplikasi, Aplikasi Pembelajaran Yoga Hindu berbasis Android telah berfungsi dengan baik sesuai dengan hasil yang diharapkan. Hasil pengujian menggunakan skala likert mendapat kategori Sangat Baik dengan nilai rata-rata $91,60 \%$.

Selain itu, pada Aplikasi Pembelajaran Yoga Hindu Berbasis Android belum tersedia fitur Zoom in untuk memperbesar gambar gerakan yoga supaya terlihat lebih jelas, tidak tersedianya alarm pengingat waktu melakukan gerakan Surya Namaskara pada Aplikasi Pembelajaran Yoga Hindu Berbasis Android, dan Video tutorial pada Aplikasi Pembelajaran Yoga Hindu Berbasis Android hanya tersedia untuk gerakan Surya Namaskara.

\section{Referensi}

[1] Timbowo, Deify. 2016. Manfaat Penggunaan Smartphone Sebagai Media Komunikasi. Fakultas Ilmu Sosial dan Politik Universitas Sam Ratulangi.

[2] Hermawan, Stephanus S. 2011. Mudah Membuat Aplikasi Android. Yogyakarta: C.V Andi.

[3] Maharta, Nengah.,dan Seruni Ni Wayan. 2014. Pengembangan dan Pendalaman Agama Hindu. Bandar Lampung: CV. Seruni.

[4] Dayuh, I Nyoman. 2016. Pengetahuan Spiritual Yoga. Kota Denpasar: Penyuluh Agama Hindu. 